\title{
Pengembangan bahan ajar ipa berbasis learning cycle $5 e$ pada pokok bahasan klasifikasi materi dan perubahannya
}

\author{
Siti Ai'syah, Safwatun Nida*, Novida Pratiwi \\ Universitas Negeri Malang, Jl. Semarang No. 5 Malang, Jawa Timur, Indonesia \\ *Penulis korespondensi, Surel: nida.safwatun.fmipa@um.ac.id
}

Paper received: 01-04-2021; revised: 15-04-2021; accepted: 30-04-2021

\begin{abstract}
Abstrak
Pembelajaran IPA menghendaki siswa aktif dalam pembelajaran. Siswa tidak hanya aktif menggunakan pengetahuannya tetapi juga aktif menggunakan keterampilan proses sains. Berdasarkan hasil observasi di salah satu SMP di Malang keterampilan proses sains siswa dan hasil belajar siswa masih rendah. Salah satu model pembelajaran yang bisa memfasilitasi siswa untuk meningkatkan keterampilan proses sains adalah Learning Cycle 5E. Penggunaan model Learning Cycle 5E dalam pembelajaran dibantu dengan bahan ajar yang berbasis Learning Cycle 5E untuk mendapatkan hasil belajar yang maksimal dan membangun keterampilan proses sains. Penelitian ini bertujuan untuk menghasilkan bahan ajar IPA berbasis Learning Cycle 5E pada pokok bahasan klasifikasi materi dan perubahannya yang layak dan valid. Model penelitian yang digunakan dalam penelitian dan pengembangan ini adalah modifikasi model pengembangan 4-D oleh Thiagarajan tanpa tahap penyebaran (Disseminate). Produk hasil pengembangan divalidasi oleh ahli media dan ahli materi, yang selanjutnya diujicobakan pada tiga guru SMP lima belas siswa kelas VII SMP. Jenis data yang diperoleh bersifat kualitatif dan kuantitatif yaitu berupa angket yang disertai saran. Teknis analisis data yang digunakan adalah analisis deskriptif kualitatif. Hasil penelitian menunjukkan bahwa kelayakan buku guru sebesar 82,4 persen dan kelayakan buku siswa sebesar 87,2 persen. Persentase kebenaran konsep sebesar 100 persen dengan kesesuaian bahan ajar dengan tahapan Learning Cycle 5E sebesar 85,6 persen. Uji keterbacaan buku guru sebesar 76 persen sedangkan uji keterbacaan buku siswa sebesar 76,15 persen. Secara keseluruhan bahan ajar yang dikembangkan mendapat kriteria layak dan valid untuk digunakan
\end{abstract}

Kata kunci: bahan ajar IPA; Learning Cycle 5E; klasifikasi materi dan perubahannya

\section{Pendahuluan}

Ilmu Pengetahuan Alam (IPA) memiliki makna sebagai produk ilmiah, proses ilmiah, dan prosedur ilmiah. Proses ilmiah diartikan sebagai metode atau kegiatan ilmiah untuk menemukan pengetahuan (Gofur, 2012). Menurut Permendikbud No. 21 tahun 2016 mengenai Standar Isi, tujuan pembelajaran IPA di tingkat SMP dalah menanamkan sikap ilmiah pada siswa, mengembangkan keterampilan proses, dan menerapkan konsep IPA untuk menyelesaikan masalah. Menurut Permendikbud No. 22 tahun 2016 mengenai Standar Proses, prinsip pembelajaran IPA adalah dari peserta didik diberi tahu menuju peserta didik mencari tahu. Oleh karena itu, pembelajaran IPA menghendaki siswa aktif dalam pembelajaran siswa tidak hanya aktif menggunakan pengetahuannya tetapi juga aktif menggunakan keterampilan proses sains.

Penerapan keterampilan proses sains dalam pembelajaran berdampak pada pemahaman konsep dan prestasi belajar siswa (Yuliati, dkk., 2015). Keterampilan proses sains penting untuk dikembangkan dan dilatihkan kepada siswa untuk mempelajari IPA. Siswa yang ingin mempelajari IPA diharapkan dapat menggunakan keterampilan proses yang dimilikinya sehingga dapat menjawab berbagai pertanyaan-pertanyaan di alam (Mutiara, dkk., 2008). Keterampilan proses sains dalam pembelajaran IPA dapat berupa penelitian, percobaan, atau praktikum (Kartimi, dkk., 2013). 
Kenyataan di lapangan menunjukkan bahwa sebagian besar siswa kurang menguasai keterampilan proses sains karena guru tidak menyediakan pembelajaran yang dapat melatih keterampilan proses sains siswa. Guru salah satu SMP di Malang sering menerapkan demonstrasi dalam menjelaskan materi kepada siswa, dengan alasan lebih mudah baik dari segi waktu, persiapan, maupun peralatan (Nida, dkk., 2017). Sebagian besar guru belum memberdayakan keterampilan proses sains melalui pelaksanaan model pembelajaran secara terus menerus dan sistematis sehingga keterampilan proses sains siswa masih tergolong rendah (Suwono, dkk., 2015). Berdasarkan hasil observasi di salah satu SMP di Malang guru belum melatih keterampilan proses sains siswa. Guru sering menayangkan video, melakukan demonstrasi, dan menyampaikan materi. Guru melakukan evaluasi sampai pada tingkat mengaplikasikan, namun tidak semua siswa dapat menjawab pertanyaan tersebut. Hal itu menunjukkan bahwa siswa kurang dilatihkan keterampilan proses sains dan hasil belajar siswa masih rendah.

Salah satu pokok bahasan IPA yang membutuhkan keterampilan proses sains adalah klasifikasi materi dan perubahannya. Klasifikasi materi dan perubahannya merupakan konsep dasar yang digunakan untuk memahami IPA pada tingkat lanjut (Kind, 2004; Iriyanti, dkk., 2012). Pemahaman siswa mengenai konsep dasar tersebut masih rendah, oleh karena itu siswa mengalami kesulitan belajar (Kirna, 2003; Laliyo, 2011). Pada pokok bahasan ini terdapat konsep yang abstrak sehingga siswa kurang termotivasi untuk mempelajarinya (Rahayu, dkk., 2016).

Model pembelajaran yang bisa memfasilitasi siswa untuk meningkatkan keterampilan proses sains salah satunya adalah Learning Cycle 5E (Sayuti, dkk., 2012). Model pembelajaran Learning Cycle $5 E$ adalah model pembelajaran yang terdiri fase-fase atau tahap-tahap kegiatan yang diorganisasikan sedemikian rupa sehingga siswa dapat menguasai kompetensi-kompetensi yang harus dicapai dalam pembelajaran dengan jalan berperan aktif (Fajaroh, dkk., 2016). Pada Learning Cycle 5E terdapat 5 tahapan belajar yaitu, engagement, exploration, explanation, elaboration, dan evaluation (Bybee, dkk., 2006).

Penggunaan model Learning Cycle 5E dalam pembelajaran dibantu dengan bahan ajar yang berbasis Learning Cycle $5 E$ untuk mendapatkan hasil belajar yang maksimal. Bahan ajar yang dibutuhkan siswa melatih keterampilan proses adalah bahan ajar yang dilengkapi dengan kegiatan percobaan. Selain itu, bahan ajar didapat dari literatur yang relevan terhadap kompetensi dasar dan materi pokok yang diajarkan kepada siswa (Yana, dkk., 2014). Berdasarkan uraian diatas, maka dilakukan pengembangan bahan ajar ipa berbasis Learning Cycle 5E pada pokok bahasan klasifikasi materi dan perubahannya.

\section{Metode}

Metode penelitian ini adalah Research and Development (R\&D) dengan model pengembangan 4-D ( Four-D Models) oleh Thiagarajan. Tahap pengembangan terdiri dari tahap pendefinisian (define), tahap perencanaan (design), tahap pengembangan (develop) dan tahap penyebaran (disseminate). Namun, Tahap penyebaran (disseminate) tidak dilakukan karena keterbatasan waktu.

Tahap pendefinisian (define) terdiri dari kegiatan analisis awal-akhir, analisis siswa, analisis tugas, analisis konsep dan tujuan pembelajaran. Tahap perencanaan (design) terdiri dari pemilihan media, pemilihan format, dan rancangan awal. Tahap pengembangan (develop) terdiri dari validasi ahli media, penilaian ahli materi dan revisi. Bahan ajar yang 
sudah divalidasi, selanjutnya dilakukan revisi berdasarkan saran dan komentar dari validator. Bahan ajar kemudian dilakukan uji coba kepada tiga guru SMP dan lima belas siswa SMP kelas VII.

Instrumen pengumpulan data dalam penelitian ini menggunakan angket yang diisi oleh validator dan subjek uji coba. Data yang diperoleh berupa data kuantitatif dan kualitatif. Data kuantitatif diperoleh dari pengisian skala likert dan skala guttman, sedangkan data kualitatif diperoleh dari saran dan komentar. Teknik penilaian yang digunakan adalah analisis deskriptif dan teknik perhitungan rata-rata. Hasil perhitungan nilai dari validator dan subjek coba diinterpretasikan ke dalam kategori sebagai berikut.

Tabel 1. Kriteria Persentase Indikator Bahan ajar

\begin{tabular}{ll}
\hline Kriteria & Persentase \\
\hline Sangat layak & $81 \%-100 \%$ \\
Layak & $61 \%-80 \%$ \\
Cukup layak & $41 \%-60 \%$ \\
Kurang layak & $21 \%-40 \%$ \\
Tidak layak & $0 \%-20 \%$ \\
\hline
\end{tabular}

(Sumber : Riduwan, 2006)

\section{Hasil dan Pembahasan}

Produk pengembangan bahan ajar ini berupa buku guru dan buku siswa. Buku guru terdiri dari halaman sampul, kata pengantar, petunjuk penggunaan, daftar isi, kompetensi inti, kompetensi dasar, tujuan dan indikator pembelajaran, materi esensial, proses pembelajaran, jawaban alternatif, teknik penilaian, kunci jawaban, dan daftar pustaka. Buku siswa terdiri dari halaman sampul, kata pengantar, petunjuk penggunaan, daftar isi, daftar gambar, daftar tabel, subbab klasifikasi materi, subbab pemisahan campuran, subbab sifat materi, subbab perubahan materi, soal evaluasi, daftar pustaka.

Bahan ajar yang telah dikembangkan dilakukan uji validasi kelayakan, uji validasi materi, dan uji keterbacaan terbatas. Uji validasi kelayakan meliputi validasi kelayakan buku guru dan validasi kelayakan buku siswa. Hasil validasi kelayakan buku guru dapat dilihat pada tabel 2 berikut.

Tabel 2. Data Hasil Validasi Uji Kelayakan Buku Guru

\begin{tabular}{|c|c|c|c|}
\hline No. & Aspek yang dinilai & Persentase & Kriteria \\
\hline 1 & Halaman sampul & $100 \%$ & Sangat layak \\
\hline 2 & Kata pengantar & $80 \%$ & Layak \\
\hline 3 & $\begin{array}{l}\text { Petunjuk penggunaan buku } \\
\text { guru }\end{array}$ & $60 \%$ & Cukup layak \\
\hline 4 & Daftar isi & $80 \%$ & Layak \\
\hline 5 & $\begin{array}{l}\text { Tujuan dan indikator } \\
\text { pembelajaran }\end{array}$ & $80 \%$ & Layak \\
\hline 6 & Materi esensial & $80 \%$ & Layak \\
\hline 7 & Proses pembelajaran & $86,6 \%$ & Sangat layak \\
\hline 8 & Teknik penilaian & $100 \%$ & Sangat layak \\
\hline 9 & $\begin{array}{l}\text { Jawaban alternatif dan kunci } \\
\text { jawaban }\end{array}$ & $80 \%$ & Layak \\
\hline 10 & Daftar pustaka & $80 \%$ & Layak \\
\hline 11 & Lay out & $80 \%$ & Layak \\
\hline \multicolumn{2}{|c|}{ Rata-rata } & $82,4 \%$ & Sangat layak \\
\hline
\end{tabular}


Berdasarkan data hasil uji kelayakan buku guru oleh ahli media diperoleh persentase sebesar $82,4 \%$ dan dinyatakan sangat layak. Hasil validasi kelayakan buku guru dapat dilihat pada tabel 3 berikut.

Tabel 3. Data Hasil Validasi Uji Kelayakan Buku Siswa

\begin{tabular}{llll}
\hline No. & Aspek yang dinilai & Persentase & Kriteria \\
\hline 1 & Halaman sampul & $94,2 \%$ & Sangat layak \\
2 & Kata pengantar & $100 \%$ & Sangat layak \\
3 & Petunjuk penggunaan buku guru & $60 \%$ & Cukup layak \\
4 & Daftar isi & $80 \%$ & Layak \\
5 & Daftar gambar & $80 \%$ & Layak \\
6 & Daftar tabel & $80 \%$ & Layak \\
7 & Kelayakan isi & $86,6 \%$ & Sangat layak \\
8 & Bagian Ayo Mencoba & $86,6 \%$ & Sangat layak \\
9 & Bagaian Ayo Belajar & $100 \%$ & Sangat layak \\
10 & Bagian Ayo Berlatih dan soal evaluasi & $100 \%$ & Sangat layak \\
11 & Daftar pustaka & $100 \%$ & Sangat layak \\
12 & Lay out & $80 \%$ & Layak \\
\hline Rata-rata & $\mathbf{8 7 , 2 \%}$ & Sangat layak \\
\hline
\end{tabular}

Berdasarkan data hasil uji kelayakan buku guru oleh ahli media diperoleh persentase sebesar $87,2 \%$ dan dinyatakan sangat layak.

Uji validasi materi meliputi uji kebenaran konsep, dan uji kesesuaian bahan ajar dengan tahapan Learning Cycle 5E. Hasil uji kebenaran konsep dapat dilihat pada Tabel 4 berikut.

Tabel 4. Data Hasil Validasi Uji Kebenaran Konsep

\begin{tabular}{llll}
\hline No. & Aspek yang dinilai & Persentase & Kriteria \\
\hline 1. & Konsep ciri-ciri zat padat & $100 \%$ & Valid \\
2. & Konsep ciri-ciri zat cair & $100 \%$ & Valid \\
3. & Konsep ciri-ciri zat gas & $100 \%$ & Valid \\
4. & Kebenaran konsep campuran & $100 \%$ & Valid \\
5. & Konsep larutan asam & $100 \%$ & Valid \\
6. & Konsep larutan basa & $100 \%$ & Valid \\
7. & Konsep larutan netral & $100 \%$ & Valid \\
8. & Konsep garam & $100 \%$ & Valid \\
9. & Konsep filtrasi & $100 \%$ & Valid \\
10. & Konsep kromatografi & $100 \%$ & Valid \\
11. & Konsep sublimasi & $100 \%$ & Valid \\
12. & Konsep sentrifugasi & $100 \%$ & Valid \\
13. & Konsep destilasi & $100 \%$ & Valid \\
\hline 14. & Konsep sifat kimia & $100 \%$ & Valid \\
15. & Konsep sifat fisika & $100 \%$ & Valid \\
16. & Konsep perubahan fisika & $100 \%$ & Valid \\
17. & Konsep perubahan kimia & $100 \%$ & Valid \\
\hline Rata-rata & $\mathbf{1 0 0} \%$ & Valid \\
\hline
\end{tabular}

Berdasarkadatan data hasil uji kebenaran konsep diperoleh persentase sebesar $100 \%$ dan dinyatakan valid. Hasil uji kesesuaian dengan tahapan Learning Cycle 5E dapat dilihat pada tabel 5 berikut. 
Tabel 5. Data Uji Kesesuaian Bahan Ajar dengan Tahapan Learning Cycle 5E

\begin{tabular}{llll}
\hline No. & Aspek yang dinilai & Persentase & Kriteria \\
\hline 1. & Subab klasifikasi materi & $80 \%$ & Layak \\
2. & Serdasarkan wujudnya & $100 \%$ & Sangat layak \\
3. & Subab unsur & $100 \%$ & Sangat layak \\
4. & Subab campuran & $80 \%$ & Layak \\
5. & Subab pemisahan campuran & $80 \%$ & Layak \\
6. & Subab sifat materi & $80 \%$ & Layak \\
7. & Subab perubahan materi & $80 \%$ & Layak \\
\hline Rata-rata & $\mathbf{8 5 , 6 \%}$ & Sangat layak \\
\hline
\end{tabular}

Berdasarkan data hasil uji kebenaran konsep diperoleh persentase sebesar 100\% dan dinyatakan sangat layak.

Uji keterbacaan terbatas meliputi uji keterbacaan terbatas oleh guru dan uji keterbacaan terbatas oleh siswa. Hasil uji keterbacaan terbatas buku guru oleh tiga guru SMP adalah sebagai berikut.

Tabel 6. Data Hasil Uji Keterbacaan Buku Guru oleh Guru

\begin{tabular}{llll}
\hline No & Aspek yang dinilai & Persentase & Kriteria \\
\hline 1 & Halaman sampul & $66,7 \%$ & Layak \\
2 & Identitas buku guru & $73,3 \%$ & Layak \\
3 & Keurutan buku guru (daftar isi) & $100 \%$ & Sangat layak \\
4 & Petunjuk penggunaan buku guu & $70 \%$ & Layak \\
5 & Bahasa yang digunakan & $86,7 \%$ & Sangat layak \\
6 & Jenis dan ukuran huruf yang digunakan & $80 \%$ & Layak \\
7 & Kompetensi inti & $66,7 \%$ & Layak \\
8 & Kompetensi dasar & $73,3 \%$ & Layak \\
\hline 9 & Indikator penyampaian kompetensi & $76,7 \%$ & Layak \\
10 & Tujuan pembelajaran & $70 \%$ & Layak \\
11 & Materi esensial & $70 \%$ & Layak \\
12 & Proses pembelajaran & $73,3 \%$ & Layak \\
13 & Teknik penilaian & $80 \%$ & Layak \\
14 & Kunci jawaban & $80 \%$ & Layak \\
\hline Rata-rata & $\mathbf{7 6 \%}$ & Layak \\
\hline
\end{tabular}

Berdasarkan data hasil uji keterbacaan terbatas buku guru diperoleh persentase sebesar $76 \%$ dan dinyatakan layak. Hasil uji keterbacaan terbatas buku siswa oleh lima belas siswa SMP adalah sebagai berikut.

Tabel 7. Data Hasil Uji Keterbacaan Buku Siswa oleh Siswa

\begin{tabular}{llll}
\hline No & Aspek yang dinilai & Persentase & Kriteria \\
\hline 1 & Halaman sampul & $72 \%$ & Layak \\
2 & Isi buku siswa & $90,6 \%$ & Sangat layak \\
3 & Identitas buku siswa & $74,7 \%$ & Layak \\
4 & Keruntutan (daftar isi) & $78,7 \%$ & Layak \\
5 & Petunjuk penggunaan & $76,7 \%$ & Layak \\
6 & Bahasa yang digunakan & $85,3 \%$ & Sangat layak \\
7 & Jenis dan ukuran huruf yang digunakan & $78,7 \%$ & Layak \\
8 & Peta konsep & $70,7 \%$ & Layak
\end{tabular}




\begin{tabular}{llll}
9 & Penyampaian materi & $68 \%$ & Layak \\
10 & Gambar & $85,3 \%$ & Sangat layak \\
11 & Kata pengantar & $74,7 \%$ & Layak \\
12 & Kegiatan belajar & $72 \%$ & Layak \\
13 & Cara kerja pada percobaan & $69,3 \%$ & Layak \\
14 & Latihan dan evaluasi & $69,3 \%$ & Layak \\
\hline Rata-rata & $\mathbf{7 6 , 1 5 \%}$ & Layak \\
\hline
\end{tabular}

Berdasarkan data hasil uji keterbacaan buku siswa diperoleh persentase sebesar $76,15 \%$ dan dinyatakan layak.

\section{Simpulan}

\subsection{Kesimpulan}

Bahan ajar yang dikembangkan telah melalui tahap uji kelayakan dan validasi. Hasil penelitian menunjukkan bahwa persentase kelayakan buku guru sebesar 82,4\% dengan kriteria sangat layak. Uji kelayakan buku siswa mendapat persentase sebesar 87,2\% dengan kriteria sangat layak. Persentase kebenaran konsep sebesar 100\% dengan kriteria valid. Uji kesesuaian bahan ajar dengan tahapan Learning Cycle $5 E$ mendapat persentase sebesar $85,6 \%$ dengan kriteria sangat layak. Uji keterbacaan buku guru mendapat persentase sebesar $76 \%$ dengan kriteria layak, sedangkan persentase uji keterbacaan buku siswa sebesar 76,15\% dengan kriteria layak. Secara keseluruhan bahan ajar yang dikembangkan mendapat kriteria layak dan valid untuk digunakan.

\subsection{Saran}

Saran yang diberikan untuk diseminasi produk adalah dengan menyebarkan bahan ajar yang dikembangkan kepada guru IPA dan siswa yang membutuhkan, serta dilakukan uji coba lapangan dengan skala yang lebih luas.

\section{Daftar Rujukan}

Bybee, R. W., Taylor, J. A., Gardner, A., Van Scotter, P., Powell, J. C., Westbrook, A., \& Landes, N. (2006). The BSCS 5E instructional model: Origins and effectiveness. Colorado Springs, Co: BSCS, 5, 88-98.

dan Kebudayaan, K. P. (2016). Permendikbud No. 22 tahun 2016 tentang Standar Proses. Jakarta: Kemendikbud.

Gazali, A., Hidayat, A., \& Yuliati, L. (2015). Efektivitas Model Siklus Belajar 5E Terhadap Keterampilan Proses Sains dan Kemampuan Berpikir Kritis Siswa. Jurnal Pendidikan Sains, 3(1), 10-16.

Ghofur, A. (2012). Handout Dasar-Dasar Sains.

Hartati, T. A. W., Corebima, A. D., \& Suwono, H. (2015). Pengaruh model pembelajaran inkuiri terstruktur dan siklus belajar 5 e terhadap keterampilan proses sains dan hasil belajar kognitif siswa pada kemampuan akademik berbeda. Jurnal Pendidikan Sains, 3(1), 22-30.

Iriyanti, N. P. (2012). Identifikasi miskonsepsi pada materi pokok wujud zat siswa kelas VII SMP Negeri 1 Bawang Tahun Ajaran 2009/2010.

Kartimi, K., Gloria, R. Y., \& Ayani, A. (2013). Penerapan pendekatan keterampilan proses dalam pengajaran biologi untuk mengetahui hasil belajar siswa pada pokok bahasan ekosistem kelas VII di SMPN 1 TALUN. Scientiae Educatia: Jurnal Pendidikan Sains, 2(1), 65-76.

Kind, V. (2004). Beyond appearances: Students' misconceptions about basic chemical ideas.

Kirna, I. M. (2003). Penerapan Strategi Realita-Analogi-Diskusi Menggunakan Multimedia untuk Meningkatkan Kualitas Pemahaman Siswa SMU Kelas I Semester I Tentang Konsep Partikel Materi, 
Zat Tunggal, Campuran, Atom dan Molekul. Jurnal Pendidikan dan Pengajaran IKIP Negeri Singaraja, 36(1).

Laliyo, L. A. R. U. (2011). Model mental siswa dalam memahami perubahan wujud zat. Jurnal penelitian dan pendidikan, 8(1), 1-12.

Mutiara, T., Miarsyah, M., Ernawati, \& Luvfiati, D. (2008). Ilmu Pengetahuan Alam. Bandung: Erlangga.

Nida, S., Mahanal, S., \& Pradana, D. (2017). Keefektifan Model Learning Cycle 5E Dipadu Teknik Mind Mapping untuk Meningkatkan Keterampilan Proses Sains Siswa SMP. PSEJ (Pancasakti Science Education Journal), 2(1).

Nasional, D. P. (2016). Permendikbud No. 21 Tahun 2016 Tentang Standar Isi Pendidikan Dasar Menengah. Jakarta: Depdiknas.

Nurhayati, H. M., Rahayu, S., \& Yahmin, Y. (2016). Pengaruh Pembelajaran Kimia Kelarutan dengan LC-5E Berkonteks SSI terhadap Keterampilan Berpikir Kritis Siswa SMA. Jurnal Pendidikan Sains, 4(4), 137143.

Ratnawati, E., Rahayu, S., \& Fajaroh, F. (2016). Pengaruh Learning Cycle-5E Berkonteks SSI Terhadap Pemahaman Hakikat Sains Pada Materi Larutan Penyangga Dan Hidrolisis Garam Siswa SMA. Jurnal Pendidikan Sains, 4(1), 25-35.

Sayuti, I., Rosmaini, S., \& Andayannhi, S. (2012). Penerapan Model Pembelajaran Learning Cycle 5E untuk Meningkatkan Sikap Ilmiah dan Hasil Belajar Biologi Siswa Kelas XI IPA 4 SMA Negeri 5 Pekanbaru. Jurnal Pendidikan, 3(1).

Yana, A. S. (2014). Pengembangan Handout Berbasis Model Sains Teknologi Masyarakat pada Materi Wujud Zat dan Perubahan Zat untuk Pembelajaran IPA Fisika SMP Kelas VII Semester 1. Pillar of Physics Education, 3(1). 